\title{
SOIL- AND LAND CLASSIFICATION IN THE OLD COASTAL PLAIN OF SURINAM ${ }^{1}{ }^{2}$ )
}

\author{
J. J. VAN DER EIJK ${ }^{3}$ ) and H. A. J. HENDRIKS ${ }^{4}$ )
}

CONTENTS

$\begin{array}{ll}\text { I } & \text { The conception "old coastal plain" } \\ \text { II } & \text { Geology, origin } \\ \text { III } & \text { Situation, area } \\ \text { IV } & \text { Soil investigations } \\ \text { V } & \text { Soil classification system } \\ \text { VI } & \text { Soil series of the old coastal plain } \\ \text { VII } & \text { Taxonomic units of higher categories } \\ \text { VIII } & \text { Soil maps; mapping units } \\ \text { IX } & \text { Land suitability map } \\ \text { X } & \text { Conclusions } \\ & \text { Literature }\end{array}$

\section{The conception: old COASTal Plain}

According to the geological classification by IJzerman (1931) in Surinam, apart from a cristalline basement and the Roraima formation, two zones of unconsolidated sediments were distinguishable, viz. one of continental alluvia, the other of fluviomarine deposits. In colloquial speech the latter was called "the coastal plain".

Research during the last few years has proved that in this coastal plain discrimination has to be made between a part of recent origin and an older part. At a series of meetings of geologists and pedologists organised by the Central Bureau for Aerial Surveys in 1950 for this purpose the names "young coastal plain" and "old coastal plain" were introduced (Syllabus, 1950).

The old coastal plain was then defined as a "type of table-land formation, immediately north of the savanna-belt ......, truncated by a winding river system, the greater part of which is now 'drowned'", whereas the young coastal plain comprises the area "stretching between this old coastal plain and the sea".

The differentiation into young and old coastal plain is shown in the first place by the difference in level and the differences in topography.

The young coastal plain for the greater part consists of swamps which as a rule are situated at roughly $1 \mathrm{~m}$ below "Surinaams Peil" (Surinam standard level) ${ }^{5}$ ). The dry parts (sandy ridges) are only a little higher (cf. GeYskes, 1952) and seldom attain more than c. $2 \mathrm{~m}$ above S.P. The old coastal plain consists, apart from the "winding river system" (better called submerged erosion gullies) of dry or only periodically waterlogged areas, the level of which varies from c. 1 to c. $7 \mathrm{~m}$ above S.P.

The submerged erosion gullies consisting of swamps become gradually

1) Received for publication August 17, 1953.

2) Publication no. 14 of the C.B.A.S.

3) Pedologist, Central Bureau for Aerial Surveys, Paramaribo, Surinam.

4) Agriculturist, Foundation for the Development of Mechanical Agriculture in Surinam, Lelydorp Project.

5) By way of comparison it may be stated that the average water-level of the Surinam river at Paramaribo is $2.1 \mathrm{~m}$ below S.P.; the highest level registered is $0.1 \mathrm{~m}$ above S.P. and the lowest $3.5 \mathrm{~m}$ below S.P. (cf. D'AUdRetsch, 1950). 
broader; they lie at approximately the same level as the swamps of the young coastal plain, into which they empty themselves.

The sections of the transect Wiawiabank-Moengo Tapoe, published by Lindeman (1953), illustrate this difference of level. This transect runs from the coast to $\mathrm{km} 10$ across the young coastal plain : the dry parts of the area south of $\mathrm{km} 10$ belong to the old coastal plain.

\section{GEOLOGY, ORIGIN}

Geologically the old coastal plain belongs to the Coropina formation which practically only here is exposed.

It may be remarked that on the geological map by IJzERMAN the southern strip of the old coastal plain is considered as belonging to the zone of the "Continental alluvia". However, this strip also belongs to the Coropina formation. The remaining part of IJzerman's "continental alluvia" now bears the name Zandery formation, whilst the young coastal formation belongs to the Demerara formation. (Schols \& CoHEN, 1953). The Coropina formation consists almost entirely of marine sediments of a lesser age than the deposits of the Zandery formation - against which they wedge out in the south - however, they are older than those of the recent Demerara formation which covers them in the north. (Schols \& Conen, 1953).

With regard to the origin of the old coastal plain it may be supposed that with the surface of the sea at a higher level than at present, a very shallow part existed before the shore line of that time, formed mainly by the Zandery formation and the schist hills area.

Owing to continuous silting up this gradually assumed the character of a tidal mud flat, consisting mainly of clay. On this tidal mud flat, at some distance beyond the shore line a number of offshore bars consisting of fine sand and fine-sandy loam were deposited close together. In contrast to the sandy ridges of the young coastal plain the bars of the old coastal plain are rarely deposited individually or in narrow bundles but nearly always as one very broad bundle of closely packed individuals.

During and after the formation of these bars silting up of the tidal mud flat plain lying behind and more or less cut off from the sea went on; this eventually may have created the periodically to permanently waterlogged area. Finally silty loams and clays were deposited here, sedimentation by the rivers possibly taking place at the same time.

The previously developed conception of the sedimentary process is supported by the interpretation of a number of granular analyses, given by ZONNEVELD (1950). For this purpose he drew the summation curves of a number of granular analyses of sand and clay samples, amongst which were specimens from the old coastal plain, on "probability paper" as designed by DoEglas \& BreZESINSKa SMITHUYZEN (1941). These were compared with similar curves which DoEGLAS (1950) considers characteristic for different ways of sedimentation. ZoNNEveLo's conclusion is that in the old coastal area sediments occur which are reminiscent of tidal flat sediments.

In consequence of a regression following the sedimentation, the entire old coastal plain was considerably truncated and parcelled into a great number of "islands", varying considerably in size. A relief inversion coupled with it, as mentioned by BAKKER (1949), was never noticed by us.

However, twisting erosion gullies, deeply penetrating these islands from all 
sides, did form. At a recent slight transgression the erosion gullies were submerged and young sea and river clay, belonging to the Demerara formation, were deposited between the islands and groups of islands. This also filled part of the erosion gullies. In a smaller portion of the erosion gullies a layer of bog peat developed. The fact that the tidal creeks mentioned by Bakker (1951) are no more than the numerous erosion gullies, so clearly visible on the aerial photos, has already been pointed out by CoHEN \& VAN DER EYK (1953). Although it is possible, of course, that they have partly developed at the site of former tidal creeks, they consequently did not obtain their present form in the sedimentation but in the erosion stage.

\section{Situation, AREA (see map)}

The remnants left after the erosion, together forming the present "old coastal plain", are found :

a in areas immediately adjoining the northern part of the Zandery formation or the schist hills area. Along the rivers and large creeks these Coropina areas form introversions which penetrate deeply into these formations in a southernly direction;

b as numerous scattered or close-set "islands" or "groups of islands", situated more to the north and surrounded on all sides by the Demerara formation.

The Central Bureau for Aerial Survey has delimited the following areas: All Surinam .......................... $144.000 \mathrm{~km}^{2}$

Young and old coastal plain together ........ , 21.000 , Young coastal plain (Demerara formation) .... " 16.000 ", Old coastal plain (Coropina formation) ....... " 4.300 ",

The greater part of this total area of the old coastal plain of c. 430.000 ha is to be found in the following areas :

a More or less coherent areas :

1 Saramacca-Para, Lelydorp-Republiek ......... c. 88.000 ha

2 North of the Wanekreek ............. , 49.000 ,"

b Strongly detached areas :

3 Nannikreek-Maratakka .............., 64.000 ,

4 Upper Commewyne-Upper Cottica ......... " 54.000 ",

5 Coesewyne-Tibiti .................. 51.000 ,

6 Wayambo ...................... 30.000 ",

7 Surnaukreek-Cassewinica $\ldots \ldots \ldots \ldots \ldots \ldots \ldots \ldots, 24.000$ "

\section{SoIL INVESTTGATION}

The first soil investigation which actually included the old coastal plain was made by the Scientific Expedition 1948-49. During this investigation for the first time the part of the old coastal plain north of the Wanekreek was interpreted as a separate "Old tidal flat landscape" (BakKen \& LaNjouw, 1949, BAKKER, 1949).

In 1949 the Central Bureau for Aerial Survey started the systematic geological and soil investigations of the aerially mapped part of Surinam (SYMPoSIUM, 1952). These investigations were naturally also carried out in the old coastal plain, sometimes in collaboration with experts of other services. 
In 1950 the organisation of the Lelydorp Project started its activities. For the development of this agricultural project on greatly divergent soil types of the old coastal plain a detailed soil map was considered necessary. This detailed mapping of the Lelydorp Project and its surroundings (HENDRIKs \& Glavimans, 1953) was followed by soil reconnaissances in adjoining areas.

Since from the investigations of the C.B.A.S. some general insight into the soil conditions of North Surinam is obtained, it is possible to ascertain how the soil types distinguishable in the old coastal plain are to be classified, in close as well as in wide connection.

\section{SOIL CLASSIFICATION SYSTEM}

It is desirable for Surinam to link up as narrowly as possible with the soil classification system applied in the U.S.A. This American system discriminates between taxonomic units and mapping units.

The taxonomic units form a hierarchical scheme whereby each time a number of units of a certain category together form one unit of a higher category. When drawing up a classification the start is made from soil series which are designated by geographical names, derived from the areas where they have been first described. They are subdivided into soil-types (within which often still a number of phases are distinguished). The soil series are united in families. The subsequent higher categories of soil classification are great soil groups, suborders and orders.

The classification into these categories was discussed by BALDWIN, KELLOG \& Thorp (1938), Kellogg a.o. (1949), and Soll Survey Staff (1951).

When on (small-scale) outline maps taxonomic units are indicated separately they often yield a very intricate map image which is difficultly legible, even when units of higher categories are used. Sorc Sunver Staff (1951, page 278) says: "In most landscapes the use of great soil groups as mapping units reduces the detail of the map far less than it reduces the length of the mapping legend. That is, a large part of the boundaries between the soil types in many areas are also boundaries between great soil groups". As will appear later in the discussion on the old coastal plain, this phenomenon also often occurs in Surinam.

In order to obtain a simpler map image, in such cases use is made of mapping units, each consisting of a number of taxonomic units which have been taken together for practical reasons but do not together form a unit of a higher category.

In the Netherlands mapping difficulties were avoided by provisionally introducing a category scheme somewhat different from the American system. Apart from soil types of the IInd and IIIrd category respectively, soil ranges and landscapes were distinguished which would have been called mapping units in the U.S.A. (EDELMAN, 1950).

A mapping unit which consists of geographically associated taxonomic units and giving a surveyable pattern is called a soil association. This can be made at any level of the category scheme. Sometimes even on detailed soil maps, soil associations have to be represented, within which units of the Ist or IInd category are grouped (soil types or soil series) : suchlike associations are called soil complexes. An association of soils which have developed from the same parent material into divergent soil series, owing to differences in relief and drainage, is called a catena. 


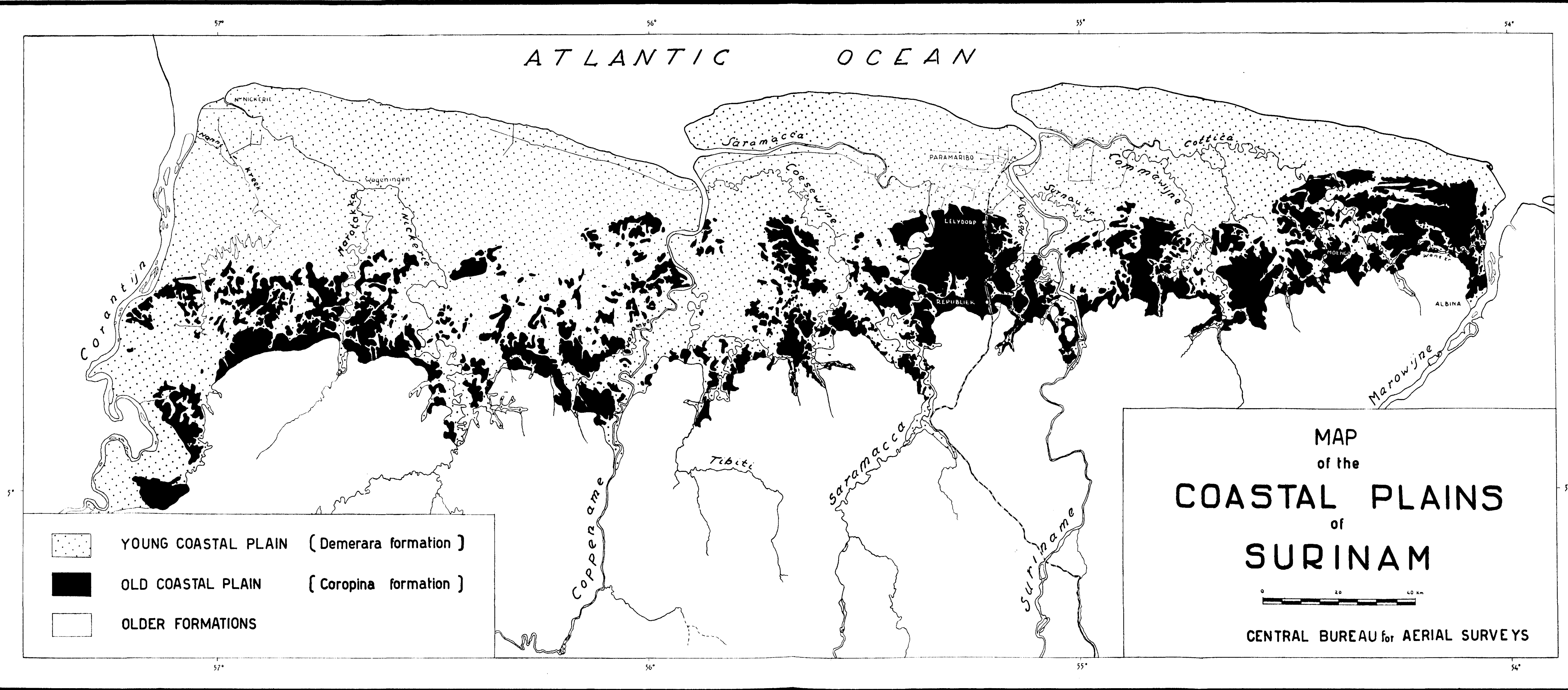


In agreement with the origin outlined in paragraph 3 , two natural landscapes can be distinguished in the old coastal plain, viz. the old offshore bar landscape and the old tidal flat landscape.

A The old offshore bar landscape is formed by the remnants of the bundles of offshore bars with the erosion gullies lying in between. In the remnants of the bundles of the offshore bars the individual bars as a rule are no longer discernible although in some places the offshore bar features still can be clearly seen. A consequence of the heavy erosion of the relatively high bars is the clearly defined relief we often find in this landscape. This relief is a very important factor for the soil formation. Hendruxs \& Glavimans (1953) distinguish ridges with reasonably good to good drainage and plateaux with poor drainage - under natural circumstances - which are therefore periodically waterlogged. Only very locally small swamps (fens) occur; these often run lengthwise of the individual bars. However, the erosion gullies filled with younger material and situated between the remnants of the offshore bars or sometimes penetrating them deeply, always consist of swamps.

In this old offshore bar landscape the following soil series are to be found:

\section{Rysdyk series}

They consist of strongly podzolised soils which have originated by continuous leaching of the soils with rain water containing humic acid. These occur on plateaux which have an insufficient superficial run-off and are situated sufficiently high above the swamp level. The higher they are situated the stronger the leaching. Qua texture they are fine sand. The series can be divided according to the depth at which the ever present humus (iron) pan occurs and the extent of the humic topsoil. The unfavourable characteristics of this series show themselves in many places by the occurrence of a vegetation of savanna forest type, or, as west of the Lelydorp Project, of pure savanna forest. The latter denomination indicate low forest of small trees only one story high, consisting of characteristic species. In the area north of the Wanekreek the iron pan occurs at such a shallow depth that the growth of trees appears to be impossible; with the result that narrow protracted open savannas have developed. (BAKKER, 1951). Here the shape of the individual offshore bars expresses itself (COHEN \& VAN DER EYK, 1953, photo 1, savanna-type Watamaleo).

In general the agricultural value is low to very low.

Description of soil profile :

$0-10 \mathrm{~cm}$ dark grey to black humic fine sand

10-105 ", whitish grey to white fine sand

$>105$, dark brown hard humus (iron) pan.

\section{Palissade series}

These soils are also podzolised. However, they are less elevated above the ground water and in the rainy season they are generally submerged. In the field "kaufoetoes" occur frequently; these are bosses of a few $\mathrm{dm}^{2}$ on the surface, separated by gullies a few $\mathrm{dm}$ deep and broad. These kaufoetoes are characteristic for periodically wet areas. Under the bleached horizon there is often a thin layer with humus accumulation; the formation of uninterrupted hardpans, however, does not occur. The discrimination within the series is 
based on the thickness of the humic top-soil and the depth of the occurrence of the loam subsoil. The agricultural value is low.

Description of soil profile :

$0-15 \mathrm{~cm}$ dark grey to black humic fine sand

$15-40$, grey fine sand

$40-60$, white fine sand

$60-70$, brownish grey humic fine sand

$>70$, pale yellow sandy loam.

\section{Onverdacht series}

These soil types are slightly podzolised; the colour of the top-soil varies from dark grey to greyish brown. Here too there is question of defective superficial drainage, although to a less extent than in the Rysdyk and Palissade series. The top layer is often considerably bleached but under this a fairly thick brown layer occurs.

The top-soil consists of sand or loamy sand and rests on a sandy loam or sandy clay. Immediately above the layer of loam the sand is more thoroughly bleached which indicates the presence of stagnant water. Within this series the depth of the impeding loam (clay) layer is the most important differential factor. A difference was made according to its presence at above $50 \mathrm{~cm}$, between 50 and $90 \mathrm{~cm}$, and deeper than $90 \mathrm{~cm}$. Further difference was made between the predominantly grey and predominantly greyish brown colour of the top-soil.

From a viewpoint of agriculture all types of this series are more or less suitable. In general the type with a deep-lying subsoil and greyish brown topsoil is the best, especially for tree crops.

Description of soil profile :

$0-15 \mathrm{~cm}$ dark grey humic loamy fine sand

15-55 „, greyish brown humic loamy fine sand

$55-70 \%$ greyish yellow loamy fine sand

$>70$ " pale yellow sandy loam.

\section{Guldenvlies series}

These are typical ridge soils with excellent superficial drainage. Qua texture they are principally loamy sands. The colour of the topsoil is dark brown to dark yellowish brown, the subsoil is ochre yellow. Within the series a discrimination can be made according to the depth at which the impeding layer occurs; this principally is an ochre yellow sandy loam, however, only occurring at the flanks at a depth less than $90 \mathrm{~cm}$. Agriculturally these sandy soils are very suitable for tree crops as well as for plough land, except for their chemical poverty which they share with almost all the soils of the old coastal plain. For plough land a flat piece on top of a ridge is preferred because of the liability to erosion. The deep rooting zone is very favourable for tree crops.

Description of soil profile :

$0-10 \mathrm{~cm}$ dark brown humic loamy fine sand

$10-50$ „ brown humic loamy fine sand

$50-80$ " yellow loamy fine sand 
80-125, ochre yellow sandy loam

125-270 " ochre yellow sandy loam, mottled with brick-red, and with brick-red concretions

$>270$, pale yellow loamy fine sand, mottled with brick-red, and with small brick-red concretions.

\section{Notoboesi series}

This series is formed by reddish brown sandy soils on a yellowish red subsoil. They occur only on the highest knolls in the landscape; consequently their total area is not large. Their profiles are well permeable, deep humic, and very deeply rooted, without impeding layers.

Agriculturally they are suitable, especially for tree crops, although annual crops might be liable to suffer from drought during a prolonged dry season.

Description of soil profile :

$0-60 \mathrm{~cm}$ dark reddish brown humic fine sand

$60-100$, dark yellowish red fine sand

$100-220 "$ yellowish red loamy fine sand

$>220$ " dark yellow loamy fine sand.

\section{Ongelegen series}

This series consists of high loamy soils and occurs predominantly high on the flanks; for this reason they have an absolutely dry situation like the Guldenvlies and Notoboesi series. They are supposed to be subsoils which became bare through erosion and afterwards weathered, since up till in the present topsoil red concretions occur. The colour of the topsoil is dark brown; the subsoil varies from ochre yellow to red. These differences in colour agree with those between the Guldenvlies and Notoboesi series; the other very slight differences of the soil profiles, however, did not call for a separation into two series.

Agriculturally these soils are suitable for tree crops but for plough land they are less suitable as the soil readily becomes compact when cultivated.

Description of soil profile:

$0-20 \mathrm{~cm}$ dark brown humic sandy loam

$20-40$, light brown sandy loam

40-80 " yellowish brown sandy loam, with soft red concretions

$>80$, ochre yellow clay loam, mottled with red, and with soft red concretions.

\section{Pararac series}

These are soils occurring in valleys. The topsoil is brown to greyish brown, varies in texture from sandy loam or silt loam to loam and contains a good deal of organic matter; the grey subsoil is a clay loam or sandy clay which at a depth of c. $90 \mathrm{~cm}$ shows a striking, strongly reddish yellow and/or red mottling.

Two "sub-series" are distinguishable, viz. the low lying loamy subsoil of the flanks exposed by erosion and the washed-in soils in the erosion valleys. Consequently, narrow strips of grey loam often occur along the botton of the flanks, these quickly changing downwards into sandy clay which is most probably identical to the deeper subsoil of the higher situated regions. 
More to the centre of the valleys lie thicker layers of loam, sometimes with small sand lenses. All these soils are more or less waterlogged and agriculturally there is little difference between the two "sub-series". The soils of the Pararac series are excellent pasture-land, especially if the water household could be improved. For tree crops, however, they are often too low and their ground water-level too high. Oilpalms and bananas, however, grow well there.

Description of soil profile:

0-10 $\mathrm{cm}$ brown humic sandy loam

10-30 „ greyish brown sandy loam

$30-75$ „yellowish grey loam

75-90 " grey clay loam, mottled with reddish yellow

$>90 "$ grey, reddish yellow and red mottled tough sandy clay.

\section{Groenhart series}

These soils form the bottom of the fens, situated in the midst of the Rysdyk series, and resting on similar white sand. They are submerged practically all the year round. It could possibly be deducted from the usual protracted shape of the fens that they originated between two offshore bars which were deposited partially over one another. Owing to washing in they contain much silt, whereas the topsoil consists of organic matter. Their agricultural value is almost negligible.

Description of soil profile :

$0-30 \mathrm{~cm}$ black peaty humus

$30-50$ " grey loamy sand to silt loam

$50-90 "$ white fine sand

$>90 "$ pale yellow sandy loam.

\section{Arapappa series}

These are clay soils which occur in the centre part of the erosion valleys, consisting of swamp. This clay which had been deposited after the valleys had been "drowned" by a small transgression is a young filling up (Demerara formation). As similar clay was deposited to a very large extent in the young coastal plain the occurrences of these soils within the area of the old coastal plain are only offshoots of the soil series which in fact belongs to the young coastal plain. There is often a thick layer of organic matter lying on the clay. As these soils are mostly submerged their agricultural value, particularly within the old offshore bar landscape, is dependent on the depth of the water. However, within reasonable limits rice culture is a possibility.

Description of soil profile :

0-25 cm dark brown peaty humus

25-55 „ dark grey humic heavy clay

$>55$ " light grey buttery heavy clay, mottled with yellow and rusty brown.

\section{Kalebaskreek series}

In these soils accumulation of organic matter to such an extent has taken place that they have to be called peat soils. This peat is low moor peat, 
developed in deep swamps from the remnants of the swamp forest. Like those of the Arapappa series, these soils do not only occur in the erosion gullies, but also in the adjoining swamps of the young coastal plain. The layer of peat is considered to belong to the Demerara formation and is often more than $2 \mathrm{~m}$ thick.

In the transition area between this series and the Arapappa series an alternation of some layers of peat and grey buttery clay is often observed. From an agricultural viewpoint these soils are valueless.

Description of soil profile :

$0-30 \mathrm{~cm}$ dark muck
$30-60 \%$ black muck
$60-120 \%$ brown peat consisting of small lumps (recognisable wood
$>120 \%$ blueish grey buttery clay with fine organic fibre.

B The old tidal flat landscape consists of the remnants of the old tidal flat ("schollen") with the erosion gullies situated in between. The actual erosion remnants are much flatter than those of the previous landscape. Although dry parts occur the condition of the region is predominantly periodically wet. Although in the dry periods the soil is perfectly dry, in the rainy season there is often a depth of one decimeter of water or more. This marked alternation in moisture is coupled with the occurrence of the already mentioned "kaufoetoes".

As in the preceding landscape the filled up erosion gullies consist of swamp. In the old tidal flat landscape the following soil series occur :

\section{Cassewinica series}

The most frequently occurring soils of the dry parts of the islands in the old tidal flat landscape belong to this series. The yellowish brown to greyish brown friable topsoil varies in texture from loamy fine sand to silt loam or silty clay; this, however, is not deep (often less than $40 \mathrm{~cm}$ ) and is succeeded by tough silty clay loam, mottled yellowish brown and grey, and subsequently a very tough and compact (silty) clay, conspicuously mottled white, purplish red and brownish yellow. Of the agricultural value of these soils practically nothing is known. It only may be observed that these soils are widely used for making "grondjes" ("fields"), especially in the Para district, but also by Indians and Bushnegroes $\left.{ }^{6}\right)$. In consequence, in various places owing to repeated burning anthropogeneous savannas originated (COHEN \& VAN DER EIJK, 1953 : savannetypes Welgelegen, dry variation).

From the analogy of this soil series to the Pararac series it may be expected that these soils will be suitable for grass-land.

Description of soil profile :

$0-2 \mathrm{~cm}$ dark brown humic friable silt loam

2-25 "yellowish brown friable silt loam

25-55 mottled brownish grey and yellowish brown tough silty clay

6) "Grondjes" are pieces cut out and burnt down in the forest; they are abandoned after the cultivation of one or two food-crops. 
$>55 \mathrm{~cm}$ mottled light grey, purplish red and yellowish brown, very tough and compact silty clay with small purplish red concretions, very heavily mottled.

\section{Waycaribo series}

These soils are the periodically waterlogged or even submerged "schollen" ("islands") in this landscape. They also occur in pronounced declines of the dryer islands or on the outer edges of these; they are therefore in the middle of or around the Cassewinica series. Owing to their very variable moisture conditions they show clearly the kaufoetoes already described which can be $1 / 2 \mathrm{~m}$ in width and depth.

The topsoil under the humic layer is grey or greyish white; the subsoil shows the same strongly red, white and yellowish brown mottling as the Cassewinica series. Qua texture these soils are silt loam or silt clays.

Extended areas of this soil series are covered by savanna forests or savannas (Welgelegen type, periodically waterlogged variety).

Description of soil profile :

0-15 cm dark grey humic blocky silt loam

15-25 " light grey friable silt loam

$25-30$ " light grey silt clay, mottled with rusty brown

50-70 " mottled light grey and yellowish brown tough silt clay

$>70$ ” tough silt clay mottled white, yellowish brown, yellowish red and purplish red with small purplish red concretions; very marked mottling.

\section{Copi series}

In the old tidal flat landscape in the vicinity of the deposits of the (coarse sandy) Zandery formation soils occur into which coarse sand from this latter formation has washed in to a greater or less extent. In the first place this admixture occurs along the northern boundary of the Zandery formation; the latter penetrates deeply into the old tidal flat landscape with numerous somewhat elevated "neuzen" ("promontories"), pointing in a northerly direction. In addition, in the midst of this landscape outcrops occur of the Zandery formation around which the same conditions may be observed. Of these soils the topsoil, often deeply humic, shows this washing in most markedly and can even consist completely of coarse sand. This decreases with the depth of the soil, and the profile first shows a yellowish brown to reddish yellow coarse sandy loam, and then a subsoil of coarse-sandy, or coarse sand containing clay, mottled white, red, and yellow. Often coarse sand and coarse sand containing clay alternate in the subsoil layers.

Description of soil profile :

0-25 cm dark brown humic loamy coarse sand

25-50 „ dark brown humic coarse-sandy loam (rich in silt)

50-70" brownish yellow coarse-sandy (and silt containing) clay

70-90" yellowish red tough coarse-sandy clay, mottled brownish yellow

$>90$ " very tough and compact sand containing clay mottled white, purplish red and yellow, with purplish red concretions. Mottling very marked. 


\section{Cordon series}

These soils occur in narrow swamps which are the top ends of the erosion gullies. Their humus content is high and can be compared with the Groenhart series of the old offshore bar landscape.

Description of soil profile:

$0-30 \mathrm{~cm}$ black strongly humic silt clay

$30-70$, dark grey humic silt clay

$>70$ " dark grey humic clay heavily mottled with yellowish red and rusty brown.

\section{Arapappa series and}

\section{Kalebaskreek series}

As in the old offshore bar landscape these two series of swamp soils occur in the erosion gullies filled with more recent material.

In the discussions above we have tried to give all the soil series of the old coastal plain that can be discriminated according to the prevailing ideas. It is, however, possible that in the yet unmapped or only reconnoitred parts other series still have to be distinguished.

It is also possible that in consequence of changing views as a result of increasing knowledge some of the so far discriminated soil series will have to be united into one series. Thus it is not inconceivable that in due course the Pararac series might be included in the Cassewinica series.

\section{TAXONOMIC UNITS OF HTGHER CATEGoRIES}

At the highest level soils are classified in three orders, two of which occur in the old coastal plain, viz. zonal and intra-zonal soils.

Only the Guldenvlies, Notoboesi, and Ongelegen series can be considered as completely zonal. The Onverdacht series is a transition case, but in all other series the factor "relief" dominates the influence of climate and vegetation factors, so that they belong to the intra-zonal soils.

The three completely zonal soil series show characteristics of laterisation as well as of podzolisation, as is often the case in tropical and subtropical regions when the parent material is rich in quartz sand or -silt. (Byers, Kellogg, ANDERSON \& THORP, 1938 ; JOFFe, 1949).

They belong therefore to those soils which form the very gradual transition between suborders "lateritic soils" and "light coloured podzolised soils".

In order to ascertain to which of these two suborders the three zonal soil series are to be assigned a number of chemical analyses were used which were carried out by the Paranam Laboratory, thanks to the kind co-operation of the Geological Department of the Surinam Bauxite Company. The results of these analyses and some ratios calculated from them are given in table 1. 


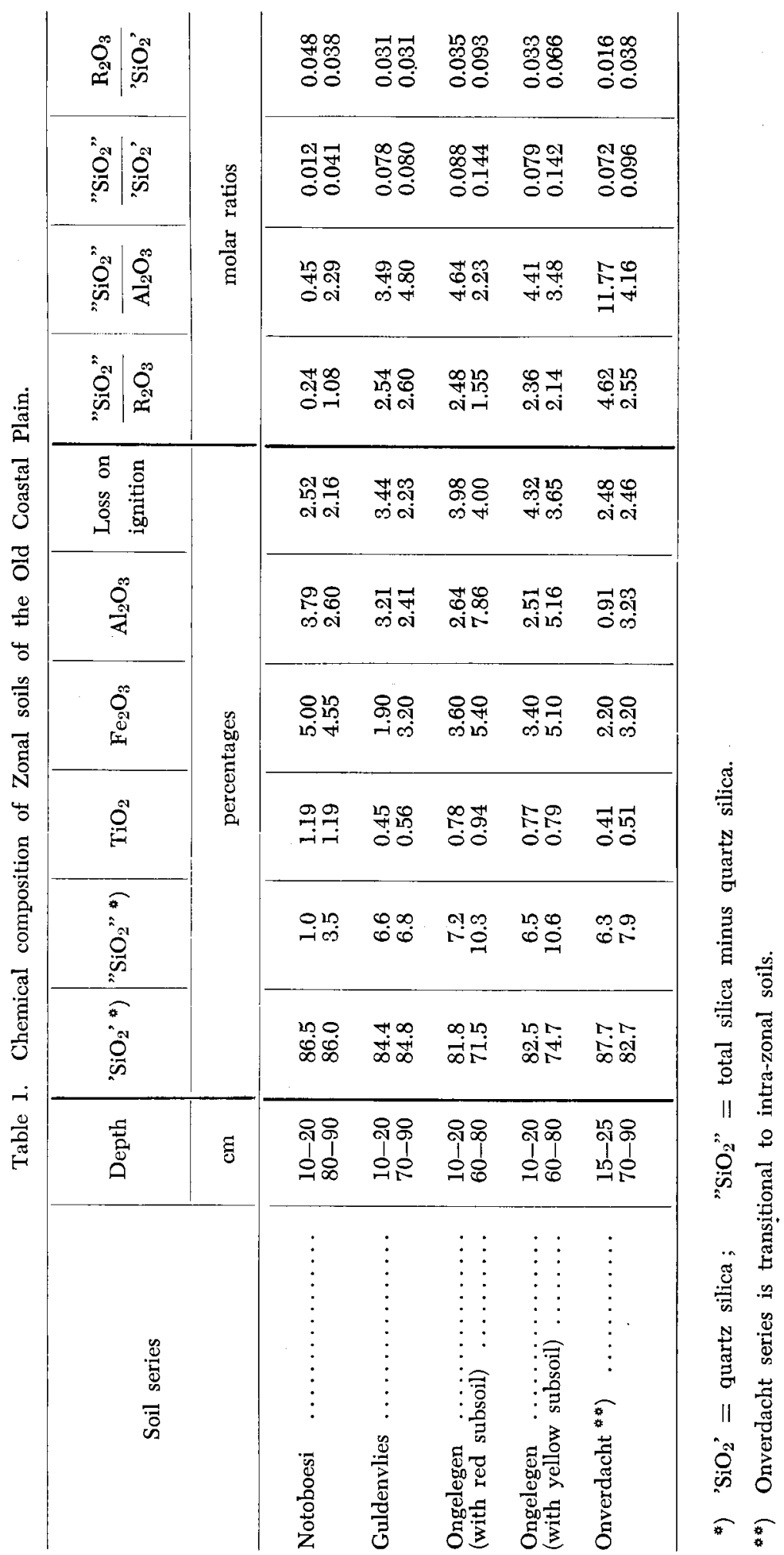


As the non-colloid fraction of these soils consists practically exclusively of quartz the ratios " $\mathrm{SiO}_{2} ": \mathrm{R}_{2} \mathrm{O}_{3}$ and " $\mathrm{SiO}_{2}$ ": $\mathrm{Al}_{2} \mathrm{O}_{3}$ practically agree with those of the colloid fraction of the soils. These figures are therefore comparable with those which are given for various soils by JoFFe (1949) and a number of authors quoted by him.

In the Notoboesi series the ratios " $\mathrm{SiO}_{2} ": \mathrm{R}_{2} \mathrm{O}_{3}$ and " $\mathrm{SiO}_{2}$ ": $\mathrm{Al}_{2} \mathrm{O}_{3}$ are very low for the topsoil and very much lower than those for the subsoil. This considerable relative loss of " $\mathrm{SiO}_{2}$ " in the topsoil points to a predominating laterisation; the ratio " $\mathrm{SiO}_{2}$ ": $\mathrm{Al}_{2} \mathrm{O}_{3}$ (ki-value of Harrassowitz), moreover, is also in the subsoil only little higher than 2.0; a value which is often considered as a border line between lateritic and non-lateritic. The value " $\mathrm{SiO}_{2}$ ": $\mathrm{SiO}_{2}$ ' increases considerably downwards whereas the value $\mathrm{R}_{2} \mathrm{O}_{3}$ : 'SiO${ }_{2}$ ' actually decreases, which also points to laterisation. On account of these ratios we assume that this soil series must be classified as belonging to the "Lateritic soils of forested, warm-temperate and tropical regions". Also the high $\mathrm{TiO}_{2}$ percentage, without any loss of it having taken place in the topsoil, is another indication. (cf. JOFFE, page 470 and 504). The great soil group to which the series belongs is that of the "Reddish Brown and Yellowish Brown Lateritic soils".

The topsoils of the Guldenvlies and Ongelegen series show much higher " $\mathrm{SiO}_{2}$ ": $\mathrm{R}_{2} \mathrm{O}_{3}$ and " $\mathrm{SiO}_{2}$ ": $\mathrm{Al}_{2} \mathrm{O}_{3}$ values than those of the Notoboesi series. In the Guldenvlies series the values for the subsoil are a little higher than those for the topsoil; in the Ongelegen series the reverse is the case. This latter fact points to a relatively greater loss of sesquioxides in the topsoil and therefore to a predominant podzolisation. Only for the red subsoil of one of the Ongelegen profiles does the ki-value approach the figure 2.0, but in all other cases, even in the Guldenvlies series, it lies considerably higher. In the Guldenvlies series the ratio $\mathrm{R}_{2} \mathrm{O}_{3}: \mathrm{SiO}_{2}$ ' is equal in the topsoil and in the subsoil, but downwards in the Ongelegen profiles strongly increases. The conclusion from these data is that these two soil series belong to the "Light colored podzolized soils of the timbered regions". The great soil group to which this series must be assigned is that of the "Red and Yellow Podzolic soils". Of a number of soil series occurring in the U.S.A. and belonging to this great soil group (Cecil, Orangeburg, Norfolk and others) chemical analyses are given by JoFrE (1949, page 490).

Compared with these the Guldenvlies and Ongelegen series show higher ki-values, from which it would follow that they are "more podzolic" than the American series mentioned. The fact that their $\mathrm{TiO}_{2}$ values increase downwards whereas in the American series an accumulation in the topsoil is noticeable (page 509) also points to this conclusion.

The Onverdacht series shows this predominant podzolisation to an even greater extent than the Guldenvlies and Ongelegen series.

This appears from the high " $\mathrm{SiO}_{2}$ ": $\mathrm{R}_{2} \mathrm{O}_{3}$ and " $\mathrm{SiO}_{2}$ ": $\mathrm{Al}_{2} \mathrm{O}_{3}$ ratios of the topsoil and the low $\mathrm{TiO}_{2}$ ratio increasing downwards. This soil series is, however, no longer to be considered as purely zonal; it forms the transition between the zonal Guldenvlies series and the intra-zonal Palissade series, to which will be referred later.

All the other - intra-zonal - soil series show an impeded drainage or are even permanently submerged. They therefore belong to the sub-order "Hydromorphic soils of marshes, swamps, seep areas and flats". However, within this sub-order they can be divided into various great soil groups. 
The highly podzolised soils of the Rysdyk series, within which a clearly defined humus (iron) pan has developed at the groundwatertable, belong to the great soil group Ground-Water Podzol soils. In the soils of the Palissade series the humus pan is much less well developed, but as humus accumulation usually has taken place this series is considered as belonging to the same great soil group.

As regards the Pararac, Cassewinica, Waycaribo- and Copi series it can be said that these do not fit into one of the hitherto differentiated great soil groups as mentioned by BaLdwin, Kellogg \& Thorp (1938) and KeLlogg a.o. (1949). For this reason the discrimination of a new great soil group is proposed, provisionally called "Strongly Mottled soils".

All these soils show a yellowish brown, greyish brown, or grey topsoil which, often via a yellowish brown intermediate horizon, passes at c. $50 \mathrm{~cm}$ into a very solid subsoil, extensively mottled with purplish red, white, and yellowish brown. Probably in due time it will become evident that the great soil group created here has to be included in one of the "recognised" great soil groups, for instance in the so-called "Low-Humic Gley soils", to which these soils bear close resemblance.

The soils of the Groenhart, Cordon, and Arapappa series, situated in the swamp, all show a peaty topsoil, under which at a depth of $30 \mathrm{~cm}$ or at the most $50 \mathrm{~cm}$ the mineral subsoil is situated. This series has therefore to be considered as belonging to the great soil group "Half Bog soils".

Finally we see how in the Kalebaskreek series the peat has reached a great depth; here the mineral subsoil often lies deeper than 2 metres. This series consequently belongs to the great soil group "Bog soils".

Table 2 gives an outline of the grouping of the soil series in great soil groups.

Table 2. Taxonomic Units of the Old Coastal Plain.

\begin{tabular}{|c|c|c|c|}
\hline Order & Suborder & Great soil groups & Soil series \\
\hline \multirow{2}{*}{ Zonal soils } & $\begin{array}{l}\text { Lateritic soils of forested } \\
\text { warm-temperate and trop- } \\
\text { ical regions }\end{array}$ & $\begin{array}{l}\text { Reddish Brown and Yel- } \\
\text { lowish Brown Lateritic } \\
\text { soils }\end{array}$ & Notoboesi \\
\hline & $\begin{array}{l}\text { Light colored podzolised } \\
\text { soils of the timbered } \\
\text { regions }\end{array}$ & $\begin{array}{l}\text { Red and Yellow Podzolic } \\
\text { soils }\end{array}$ & $\begin{array}{l}\text { Guldenvlies } \\
\text { Ongelegen }\end{array}$ \\
\hline \multirow{4}{*}{$\begin{array}{l}\text { Intra-zonal } \\
\text { soils }\end{array}$} & \multirow{4}{*}{$\begin{array}{l}\text { Hydromorphic soils of } \\
\text { marshes, swamps, seep } \\
\text { areas and flats }\end{array}$} & $\begin{array}{l}\text { Ground-Water Podzol } \\
\text { soils }\end{array}$ & $\begin{array}{l}\text { Palissade } \\
\text { Rysdyk }\end{array}$ \\
\hline & & Strongly Mottled soils & $\begin{array}{l}\text { Pararac } \\
\text { Cassewinica } \\
\text { Waycaribo } \\
\text { Copi }\end{array}$ \\
\hline & & Half Bog Soils & $\begin{array}{l}\text { Groenhart } \\
\text { Cordon } \\
\text { Arapappa }\end{array}$ \\
\hline & & Bog Soils & Kalebaskreek \\
\hline
\end{tabular}




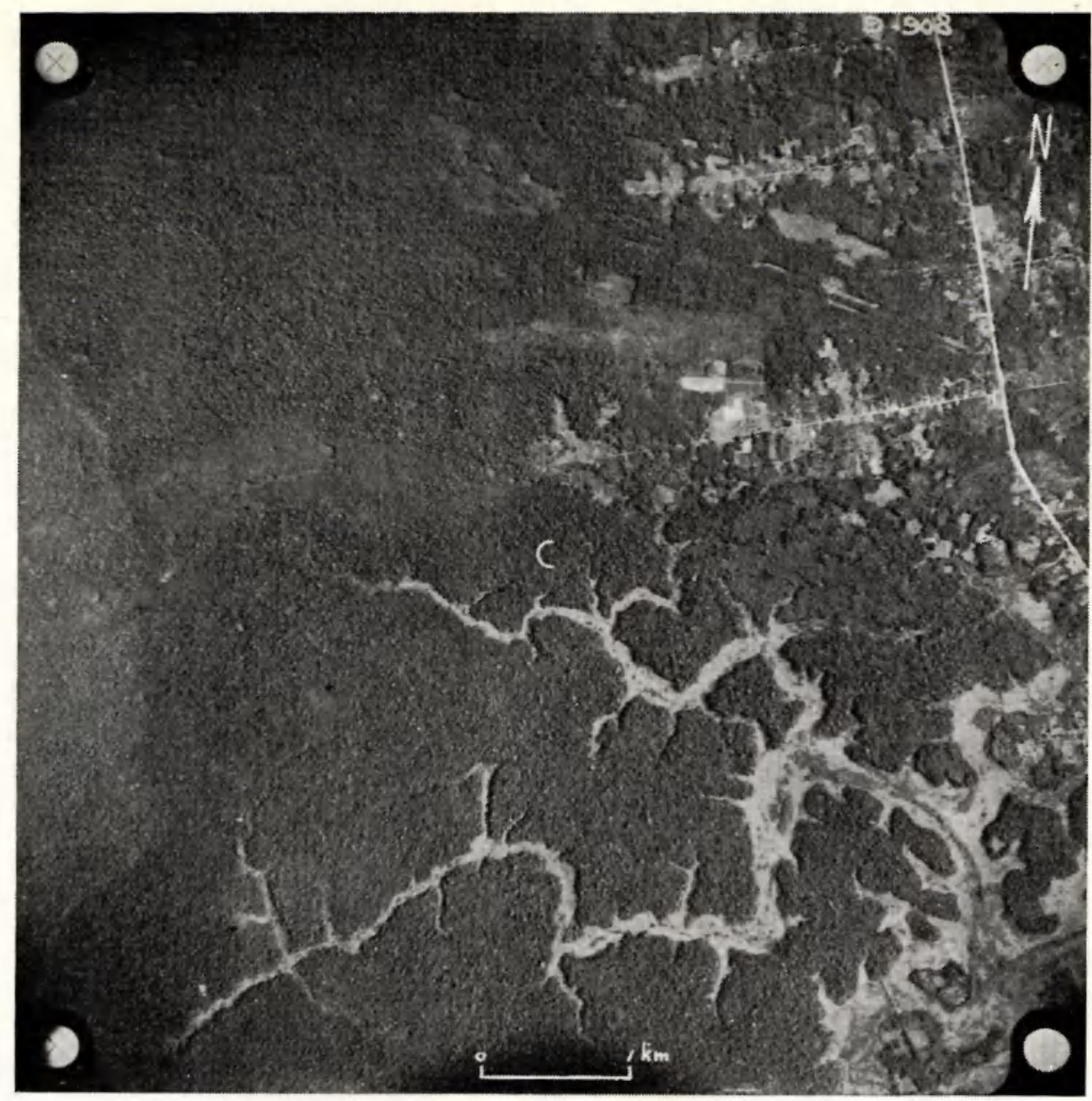

Fig. 1. Aerial photograph of a part of the old coastal plain, S. of Paramaribo.

Except for the N.E. quarter, where clearings along the roads and second-growth dominate, the old offshore bar soils and the old tidal flat soils are covered with primary forest. The two soil associations carry different, on the photo distinguishable types of this forest vegetation.

In the virgin area, the plateaus where the Rysdyk series occurs are indicated by savanna forest. The fens of the Groenhart series have a poor vegetation of grasses and ferns. Form and situation of these plateaus and fens show the direction of the original offshore bars. Declines, where the Waycaribo series occurs, are also covered with savanna forest. The submerged erosion gullies, consisting of the Arapappa series, have a low vegetation of grasses, herbs and scrubs. In the top-ends they carry swamp forest.

Copyright C.B.A.S.

Original scale $1: 40.000$. 


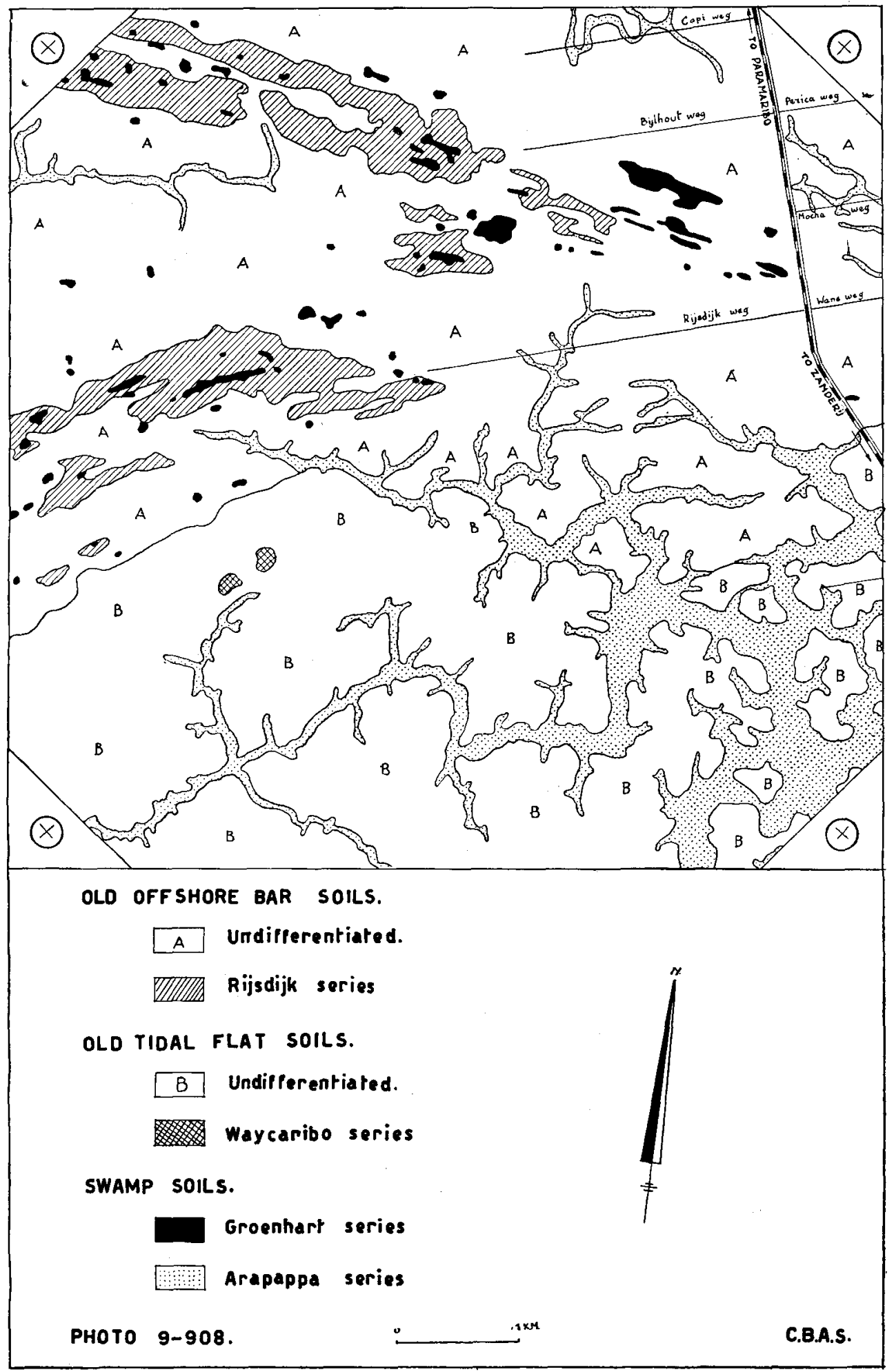

Fig. 2. Pedologic conclusions from opposite aedial photograph. 


\section{SOIL MAPS, MAPPING UNITS}

During the soil survey of the Lelydorp Project it became apparent that because of the very complex soil pattern a scale of 1 : 10.000 is essential for showing the soil series of the old offshore bar landscape. Such a map must be regarded as a detailed map.

For the publication on a scale $1: 20.000$ several soil series approximately similar in agricultural character were united into a group so that the ultimate legend of this map (Hendriks \& Glavimans, 1953) reads as follows ${ }^{7}$ ):

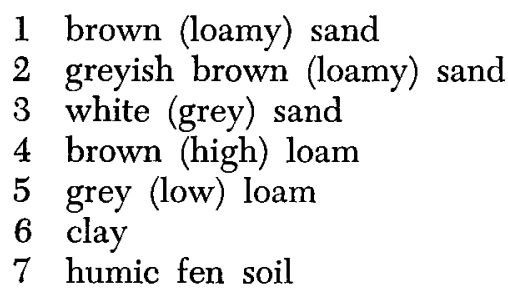

$$
\begin{aligned}
& \text { (= Notoboesi-Guldenvlies complex) } \\
& \text { (= Onverdacht series) } \\
& \text { (= Rysdyk-Palissade complex) } \\
& \text { (= Ongelegen series) } \\
& \text { (= Pararac series) } \\
& \text { (= Arapappa series) } \\
& \text { (= Groenhart series) }
\end{aligned}
$$

For mapping soil types or phases, a scale 1 : 5.000 is necessary. Such maps are available at the Lelydorp Project and are used as farm management maps. In the old tidal flat landscape no detailed soil survey has yet been made; however, from many reconnaissances the impression was obtained that for mapping the soil series a scale $1: 20.000$ is sufficient.

It is clear that for obtaining a general view maps at a smaller scale than those mentioned here are necessary.

For the reconnaissance maps in the first place the scale $1: 100.000$ (survey scale $1: 40.000)$ is considered. These are the scales of the controlled photomosaics of the northern half of Surinam and the topographical maps made from these. Of the 10 soil series of the old offshore bar landscape, 9 occur in the Lelydorp area and belong to 5 great soil groups. From the soil maps by Hendriks \& Gravimans it becomes evident that these great soil groups are no suitable map units for a scale 1:100.000. This is a consequence of the phenomenon previously mentioned that a considerable part of the boundaries between the soil series are also the boundaries between the great soil groups. The soil series Notoboesi, Guldenvlies, Onverdacht, Palissade and Rysdyk form a continuous series which show an example of how, through differences in relief, strongly divergent soil series have developed from the same parent material (fine sand). The association of successively these Reddish Brown Lateritic soils and finally Ground-Water Podzol soils is therefore a catena (cf. JENNY, 1941, page 93-98). Such catenas are the most suitable mapping units for outline maps (EDElman, 1941, page 61). As the Ongelegen and Pararac series take up too small strips when represented separately at the scales considered here they also are included in this association. These series are developed from the parent material which qua texture is a little heavier but for the rest is similar. Thus, the conception catena is used in a somewhat wider sense, as is also the case in East Africa (Mulne, see in Sorl Survey Staff, 1951, page 160). The catena of the 7 series mentioned here, which for simplicity's sake will be called "walgronden" (old offshore bar soils), form a natural unit, easily mappable at the scale $1: 100.000$. In addition this grouping gives the not essentially

7) Owing to a misunderstanding this map was printed and published on a scale $1: 30.000$. 
but practically important advantage that these old offshore bar soils are identifiable on the aerial maps and therefore mappable very accurately from the photo mosaics after some field reconnaissances through photo interpretation (see aerial photo and map).

In the old tidal flat landscape, the Cassewinica and Waycaribo series form a catena sensu strictu. United with the Copi series, containing coarse sand, these form a natural unit which is called old tidal flat soils ("scholgronden"). Similarly to the old offshore bar soils these can be accurately mapped from the aerial photos and represented at the scale $1: 100.000$.

The four series Groenhart, Cordon, Arapappa and Kalebaskreek are included in the association swamp soils ("moerasgronden"), in which other soil series, occurring outside the old coastal plain, are also grouped. The two latter series which are situated on the introversions of the Demerara formation, in the old tidal flat landscape as well as in the old offshore bar landscape, in fact also occur on a large scale in the swamps of the young coastal plain. The association swamp soils, therefore, is, only to a small extent situated within the old coastal plain. This association can also be mapped from the aerial photos.

Apart from the reconnaissance maps mentioned here, a map is also being made which at a glance allows a general view of a great part of Surinam. The scale of this generalized map is $1: 400.000$. On this small scale only the natural landscapes can be mapped in full : for the old coastal plain these are the old offshore bar and the old tidal flat landscape. These landscapes are the largest soil associations the mapping of which still has some value in view of the already existing geological map by ScHols \& CoHEN (1953).

Table 3. Mapping Units of the Old Coastal Plain.

\begin{tabular}{|c|c|c|c|c|}
\hline $\begin{array}{l}\text { Kind of } \\
\text { soil map }\end{array}$ & $\begin{array}{l}\text { Farm } \\
\text { management } \\
\text { map }\end{array}$ & Detailed map & Reconnaissance map & Generalized map \\
\hline Scale & $1: 5.000$ & $\begin{array}{l}1: 10.000 \text { or } \\
1: 20.000\end{array}$ & $\begin{array}{l}\text { Drafted in detail from } \\
\text { photo-mosaics } 1: 40.000 \\
\text { reduced } 1: 100.000\end{array}$ & $1: 400.000$ \\
\hline $\begin{array}{l}\text { Units shown } \\
\text { on the map }\end{array}$ & $\begin{array}{l}\text { Soil types } \\
\text { and phases }\end{array}$ & $\begin{array}{l}\text { Soil series } \\
\text { (and/or -com- } \\
\text { plexes) }\end{array}$ & $\begin{array}{l}\text { Soil associations } \\
\text { (resp. catenas) }\end{array}$ & Natural landscapes \\
\hline \multirow{4}{*}{$\begin{array}{l}\text { Names of } \\
\text { the Units } \\
\text { in the } \\
\text { Old Coastal } \\
\text { Plain }\end{array}$} & \multirow{4}{*}{$\begin{array}{l}\text { Not yet } \\
\text { uniformly } \\
\text { defined }\end{array}$} & $\begin{array}{l}\text { Notoboesi } \\
\text { Guldenvlies } \\
\text { Onverdacht } \\
\text { Palissade } \\
\text { Rysdyk } \\
\text { Ongelegen } \\
\text { Pararac }\end{array}$ & Old offshore bar soils & \multirow[t]{2}{*}{$\begin{array}{l}\text { Old offshore bar } \\
\text { landscape }\end{array}$} \\
\hline & & $\begin{array}{l}\text { Groenhart } \\
\text { Arapappa } \\
\text { Kalebaskreek }\end{array}$ & Swamp soils & \\
\hline & & $\begin{array}{l}\text { Cassewinica } \\
\text { Waycaribo } \\
\text { Copi }\end{array}$ & Old tidal flat soils & \multirow{2}{*}{$\begin{array}{l}\text { Old tidal flat } \\
\text { landscape }\end{array}$} \\
\hline & & $\begin{array}{l}\text { Cordon } \\
\text { Arapappa } \\
\text { Kalebaskreek }\end{array}$ & Swamp soils & \\
\hline
\end{tabular}


Apart from the two landscapes of the old coastal plain, in the part of Surinam reconnoitred by the Central Bureau for Aerial Mapping still 8 other landscapes occur (CoHEN \& VAN DER EIJK, 1953). Within this area, soil associations or catenas can be discriminated in a manner similar to that above describes. In this way the reconnaissance mapping of all 10 landscapes is carried out in a uniform manner. Table 3 gives a survey of the units to be mapped on various scales with, for the old coastal plain, the names of these units.

\section{LAND SUTTABILITY MAP}

The classification of the soils in soil series (and groups) as represented on the soil map of the Lelydorp Project and adjacent area (Hendrixs \& GLAviMANS, 1953) was made on the basis of inherent, natural characteristics of the soils. In order to arrive at a land use as rational as possible, the soil series have to be graded according to their suitability for different crops. For the determination of this suitability yield data must be gathered in an area such as the old coastal plain the production abilities of which are completely unknown.

This research is now being made at the Lelydorp Project for the soil series occurring there.

For the grasses some insight into the production levels of the four most important soil series has already been obtained. During one year the yields were ascertained from experiment fields situated on these various soil series for 6 pasture grasses and 4 soilage grasses (DiRven \& HeNDriks, 1953). If we take the lowest production as 1 we obtain the following proportional values of the yields of this year:

$\begin{array}{ll}\text { Rysdyk series } & 1 \\ \text { Guldenvlies series } & 4 \\ \text { Ongelegen series } & 4 \\ \text { Pararac series } & 8\end{array}$

The yield determinations of these experiment fields is being continued.

The impression was obtained that for the annual crops the soils of the Guldenvlies series are the best whilst also on the Notoboesi, Onverdacht, and Ongelegen series good results can be achieved. Yield data which are being collected will show whether this impression is correct.

For tree crops, four of the most important crops - cocoa, oil palm, cocos and citrus - have been observed on the various series, each time blocks of 16 plants being selected, and provisionally growth measurements will be made. Obviously, when these crops are in production yield determination will be made.

For rice fields only the swamps can be considered. Reasonable yields only can be expected in the not too deep valleys of the Arapappa series. As within the Lelydorp Project the area of these is very small rice growing will be of very secondary importance.

Summarizing it can be said that a quality classification of the soil series occurring in the Lelydorp Project may be reached for grassland fairly quickly ; for annual crops the yield observations will take another few years and for the tree crops about another decade. When the yield capacities of the various soils are sufficiently known the soil series can be grouped in a limited number 296 
of land suitability classes and for each class the most suitable type of agriculture (grassland, plough land, tree crops, or rice fields) may be stated.

Subsequently, from the present soil map a land suitability map can be made on which the suitability classes are indicated. Part of the boundaries between the soil series, thereby, will consequently be dropped whereas those which form the boundaries of the suitability classes will be maintained. (cf. the "Map showing suitability of soils for various cultures under glass" by vaN LiERE (1948) and the "Land classification map for horticulture by BENNEMA \& van DER MEER (1952).

From this land suitability map can be read immediately for which type of agriculture the various areas are suitable.

When in the Lelydorp Project the grouping of soil series in land suitability classes discussed here has been carried out it can also be applied in other parts of the old offshore bar landscape. Once the soil series being mapped in these areas a land suitability map can be made immediately.

\section{$\mathrm{X}$ Conclusions}

1 In the Surinam coastal plain a recent and an older part can be distinguished, respectively indicated as the young and the old coastal plain.

2 In contrast to the young coastal plain the old coastal plain does not form a united zone but it consists of a great number of isolated and very scattered features.

3 These consist mainly of dry or only periodically waterlogged soils. Their total area is c. 430.000 ha, i.e. c. $21 \%$ of the entire coastal plain.

4 In the old coastal plain two natural landscapes can be discriminated, viz. the old offshore bar landscape, occupying c. $35 \%$, and the old tidal flat landscape, occupying c. $65 \%$.

5 The old offshore bar landscape mainly consists of sandy and sandy loam soils within which provisionally 7 soil series, belonging to 2 zonal and 2 intra-zonal great soil groups, are distinguished. These soil series form a catena, to be indicated as old offshore bar soils ("walgronden").

6 The old tidal flat landscape mainly consists of silt loam and silty clay soils, soils containing coarse sand also occurring. Within these soils provisionally 3 soil series are discerned which belong to one intra-zonal great soil group that occurs also in the other landscape. These soil series collectively are indicated as old tidal flat soils ("scholgronden").

7 Smaller areas of the two landscapes are occupied by 4 soil series belonging to two intra-zonal great soil groups, together to be described as swamp soils.

8 The old offshore bar soils, old tidal flat soils and swamp soils are identifiable on the aerial photographs, mappable from the controlled photo mosaics and they can be represented on a scale $1: 100.000$.

On a detailed soil map (1: 10.000) of the Lelydorp Project and surroundings (c. 1500 ha), within the old offshore bar landscape, soil series are given; on a farm management map (1 : 5.000) of the same area, soil types and phases.

For making a land suitability map of this area yield data are collected.

\section{LiTERATURE}

Audnetscr, F. C. D': Verzamelde gegevens over waterboringen in Suriname (1950), bijlage 2. Meded. Geol. Mijnb. Dienst Suriname no. 5.

Bakken, J. P. : Opmerkingen over de bouw en de reliëfvormen van Suriname (1949). Programmaboekje 28ste Indische vacantiecursus voor geografen.

- - : Bodem en bodemprofielen van Suriname, in het bijzonder van de Noordelijke savannestrook. Landbouwk. Tijdschr. 63 (1951) no. 6.

- - and J. Lanjouw: Indrukken van de natuurwetenschappelijke Expeditie naar Suriname 1948-'49. Tiidschr. Kon. Ned. Aardr. Gen. 66 (1949) no. 5. 
Baldwin, M., C. E. Kellogg and J. Thorp: Soil classification. Soils \& Men, U.S. Dept. Agr. Yearbook, 1938.

Bennema, J. and K. van Der MeER: De bodemkartering van Walcheren. Versl. Landbouwk. Onderz. no. 58.4, serie: De Bodemkartering van Nederland, dl. XII, 's-Gravenhage (1952).

Byers, H. G., C. E. Kellogg, M. S. Anderson and J. Thorp : Formation of soil. Soils \& Men, U.S. Dept. Agr. Yearbook (1938).

Conen, A. and J. J. van DER ErJK: Klassificatie en ontstaan van savannen in Suriname. Geologie en Mijbouw nw.s. 15 (1953) no. 6.

Dirven, J. G. P. and J. A. H. Hendriks : Grasgroei op vier grondsoorten van het Lelydorpplan. De Surinaamse Landbouw, 1 (1953) no. 2. Dep. L.V.V., Paramaribo.

Doegras, D. J. : De interpretatie van korrelgrootte-analysen. Verh. Ned. Geol. Miinb. Gen. Geol. Serie 15 (1950).

- - and W. C. Brezesinska SMithuizen: De interpretatie van de resultaten van korrelgrootte-analysen. Geol. en Mijnb. 3 (1941) no. 11 en 12.

Edelman, C. H. : Studiën over de Bodemkunde van Nederlandsch Indië, Wageningen (1941). - - : Inleiding tot de Bodemkunde van Nederland. Amsterdam (1950).

Geyskes, D. C. : On the structure and origin of the sandy ridges in the coastal zone of Surinam. Tijdschr. Kon. Ned. Aardr. Gen. 69 (1952) no. 2.

Hendriks, H. A. J. and E. J. H. Glavimavs : Bodemkaartering van het Lelydorpplan en omgeving. De Surinaamse Landbouw, 1 (1953) no. 3. Dep. L.V.V., Paramaribo.

JENNY, H. : Factors of soil formation. New York \& London (1941).

Jofre, J.: Pedology. 2nd ed., New Brunswick (1949).

Kellogg, C. E. a.o.: Soil classification. Soil Science, 67 (1949) no. 2.

LIERE, W. J. vaN: De bodemgesteldheid van het Westland. Versl. Landbouwk. Onderz. no. 54.6, serie: De Bodemkartering van Nederland, dl. II, 's-Gravenhage (1948).

Lindeman, J. C. : The vegetation of the coastal region of Surinam. Utrecht (1953).

Schols, H. and A. CoHen : Geologische overzichtskaart. Jaarversl. 1950. Geol. Mijnb. Dienst Suriname (1950).

- - : De ontwikkeling van de geologische kaart van Suriname. Geol. en Miinb., nw. s. 15 (1953) no. 6.

SoIL Sunvey STAFF: Soil Survey Manual. U.S. Dept. Agr. Handbook no. 18 (1951).

Syludaus : Geologisch onderzoek Kustvlakte. Centraal Bureau Luchtkaartering, Paramaribo (1950).

Symposium: The use of aerial photographs in a tropical country. (Surinam). Photogr. Eng. XVIII, no. 1 (C.B.L. publ. 7) (1952).

IJzerman, R.: Outline of the Geology and Petrology of Surinam. (Dutch Guyana). Den Haag (1931).

ZonNEverD, J. I. S.: Opmerkingen naar aanleiding van analyses van enkele Surinaamse sedimenten. Jaarversl. 1950. Geol. Mijnb. Dienst Suriname (1950).

\section{RECTIFICATION}

"Control of the waterlevel in faintly sloping areas" by F. van SCHagen. On p. 169, alinea 8 from top, the formula should be read as follows:

$$
\mathrm{Q}=\ldots \ldots \ldots . . .=1.7 \mathrm{~m} . \mathrm{b} . \mathrm{h}_{1}^{3 / 2}
$$

"Insecticides against aphid vectors of potato viruses" by D. Hille Ris LaMbers, A. J. Reestman and A. Schepers.

page 190 , line 14 : instead of " $1 \%$ " read " $0.1 \%$ ".

page 193, line $2:$ instead of " $1 \%$ " read "0.1\%".

page 195, line 21 : instead of "cources" read "sources".

page 196, line 2 after table 10 : instead of "vide p .." read "vide p. 193". 